Historic, Archive Document

Do not assume content reflects current scientific knowledge, policies, or practices. 

aSD11.A48

\title{
GENETIC VARIATION IN SOUTHERN IDAHO PONDEROSA PINE PROGENY TESTS AFTER 11 YEARS
}

\author{
Gerald E. Rehfeldt
}

USDA Forest Service General Technical Report INT-75

FOREST SERVICE, U.S. DEPARTMENT OF AGRI CULTURE INTERMOUNTAIN FOREST AND RANGE EXPERIMENT STATION 


\section{THE AUTHOR}

GERALD E. REHFELDT is a plant geneticist at the Forestry Sciences Laboratory, Moscow, Idaho. Primary emphasis of his research is on the ecological genetics of northern Rocky Mountain conifers.

\section{ACKNOWLEDGMENT}

The data presented herein were provided by the Southern Idaho Tree Improvement Committee, a cooperative composed of Region 4, USDA Forest Service; Idaho Department of Lands; Bureau of Land Management, Boise District; and the Southern Idaho Forestry Association, Inc. Special acknowledgment is offered to Ronald Hamilton, USDA Forest Service, Ogden, Utah, for accumulating records, providing historical background, and criticizing the manuscript. Hans Nienstaedt, USDA Forest Service, Rhinelander, Wisconsin, and Glenn Jacobson, USDA Forest Service, McCall, Idaho, also provided comments on the manuscript. Stephen Wells, USDA Forest Service, Moscow, Idaho, provided excellent technical assistance. 


\section{GENETIC VARIATION IN SOUTHERN IDAHO PONDEROSA PINE PROGENY TESTS AFTER 11 YEARS}

Gerald E. Rehfeldt

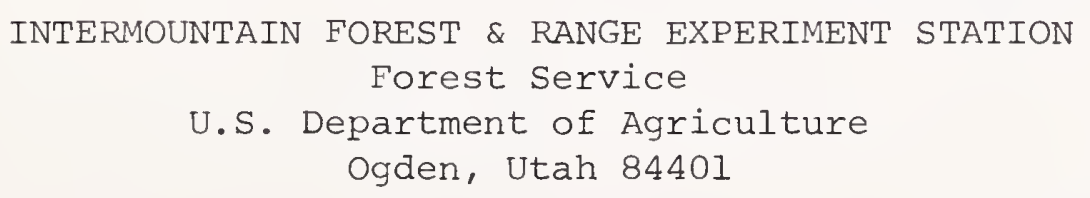




\section{RESEARCH SUMMARY}

Comparisons were made among 268 half-sib families of ponderosa pine from 37 southwest Idaho populations at four test sites. Data involved 8- and ll-year height, the percentage of trees damaged by snow, and the percentage of trees with straight stems. Analyses of variance evidenced population differentiation for height at both ages but not for the percentages of snow-damaged or straight-stemmed trees. Differences among populations accounted for about 20 percent of the genetic variance; most of the genetic variance occurred within populations.

Multiple regression analyses were made to relate population differentiation to geographic and ecologic variables. The data suggested that elevation of the seed source controlled differentiation; latitude and longitude were secondary; and habitat types were not important. From these results, it was concluded that seed for afforestation should not be transferred more than $450 \mathrm{~m}$ elevation, 1.7 degrees longitude, and 2.2 degrees latitude.

Quantitative genetic analyses provided estimates of family heritabilities in ll-year height that ranged from 0.37 to 0.53 for the various planting sites. These heritabilities imply that genetic gains of about 7 percent can be expected readily in the ll-year height of progenies of selected families.

\section{CONTENTS}

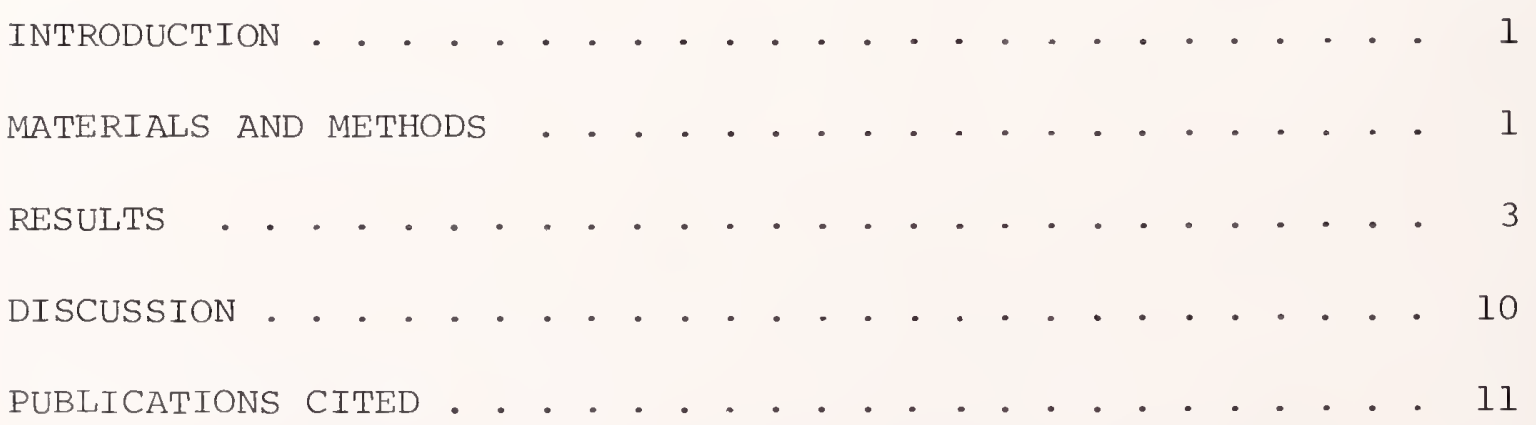




\section{INTRODUCTION}

Tree improvement offers genetic gains at three levels. First, by accounting for ecological adaptations of populations, seed zones limit losses in productivity from maladaptation. Second, progeny tests identify individual trees and populations of exceptional characteristics for siring subsequent generations. And third, intensive tree improvement provides maximal genetic gains in productivity through matings of select families within adaptated populations. Gains at the first two levels are readily realized. But, realization of the potential genetic gains begins with the yield of genetically improved seeds from seed orchards developed from parentage of known performance.

During the last 15 years, a practical tree improvement program has been developed for ponderosa pine (Pinus ponderosa) in southwestern Idaho. As explained previously (Wang 1967; Wang and Patee 1974, 1976), the program was begun to assess the genetic gains expected to accrue from seed zoning, from population selections within zones, and from family selections within populations; and to provide materials and information prerequisite to the establishment of seed orchards.

Because of a high economic value, tree improvement of ponderosa pine has received considerable attention. As reviewed by Wang (1977), genetics research was begun early in the twentieth century. Today, numerous research programs annually update and augment the genetics literature of the species. In fact, practical tree improvement programs exist in nearly every state included by the species' natural range. In addition, ponderosa pine has been subject to domestication programs in Europe, Australia, and eastern North America.

The present report assesses the performance of progenies included in the southwest Idaho tree improvement program, a cooperative of federal, state, and private forest organizations. The performance of progenies at ages 8 and 11 is related to gains anticipated in an intensive tree improvement program.

\section{MATERIALS AND METHODS}

Since procedures of cone collections and plantation establishment have been documented (Wang and Patee 1976), a brief summary will suffice. Wind-pollinated cones were collected from 1 to 10 trees in each of 37 populations (fig. 1). Populations were separated by about 2 degrees in latitude and longitude. Within this area, most of the ecological amplitude of the species was represented. Populations were from elevations as low as $975 \mathrm{~m}$ and as high as $1980 \mathrm{~m}$. Habitat types varied from the relatively dry Pinus ponderosa/Purshia tridentata to the relatively moist Abies grandis/Vaccinium globulare.

Two-year-old seedlings from 268 families were planted in 4 -tree row plots in 10 replicates at 4 planting sites. About $1.5 \mathrm{~m}$ separated trees within rows; $3 \mathrm{~m}$ separated rows. Test sites (fig. 1) included Idaho City (1 $200 \mathrm{~m}$ elevation), Holcomb (1 $100 \mathrm{~m})$, Boulder Creek (1 $450 \mathrm{~m}$ ) and Jack's Creek (1 $650 \mathrm{~m}$ ). 


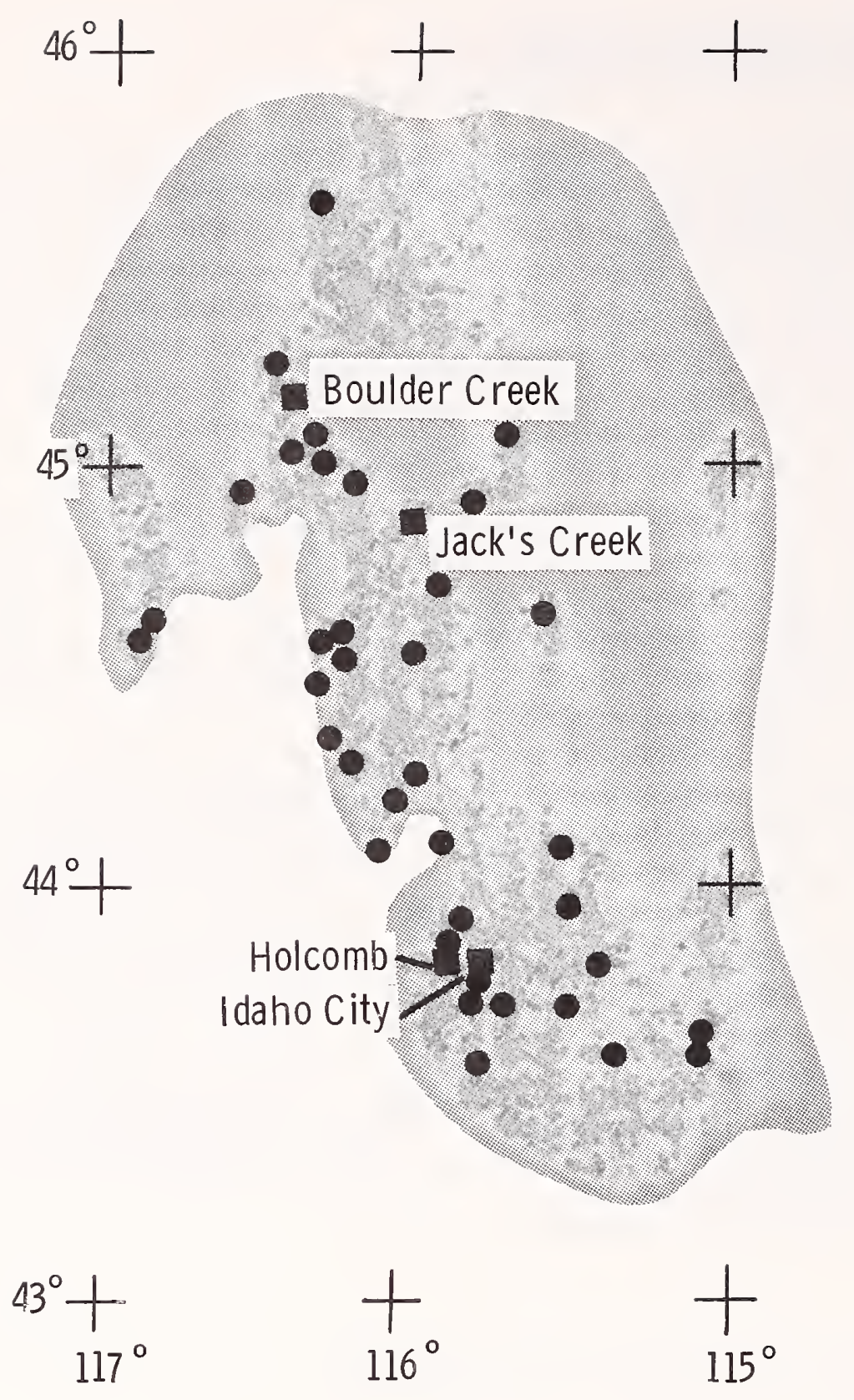

Figure 1.--Location of populations (dots) and test sites (squares) shaded area represents distribution of forested lands.

Measurements of the height of individual trees had been made at ages 8 and 11 . At age 11, stem straightness was also scored on a scale of 1 to 4 : 1 = straight stem, 4 = severe crook. In addition, injuries to each tree were classified as the presence or absence of damage from rodents, insects, disease, snow, water and large mammals.

Statistical analyses were made to estimate genetic components of variance in the height of progenies at ages 8 and 11. Tests of chi-square were used to assess stem straightness and snow damage to trees at Boulder Creek. Only data from Boulder Creek were included in the latter analyses because scores of stem straightness and injuries were either invariate or randomly distributed at the other test sites; damage from snow was exceptionally high at Boulder Creek. Finally, multiple regression analyses were used to relate population differentiation to geographic and ecologic variables of the seed source. 


\section{RESULTS}

Analyses of variance were made according to a least squares fit to the model presented in table 1 for height at ages 8 and 11. Similar analyses were made for a measure of growth rate between ages 8 and 11 where growth rate was expressed as the deviation from regression of 11-year height on 8-year height. But the relationship between height at the two ages was so strong $(r=0.89)$ that deviations from regression were essentially randomly distributed. Since no genetic effects were apparent in analyses of growth rate, results of analyses are not presented.

Analyses were made separately for data from each plantation. Separate analyses were necessary because of an extreme imbalance in the representation of families among replicates and planting sites. Imbalances in the original design had been confounded further by survival percentages of 22, 42, 63 and 80 percent at Jack's Creek, Holcolmb, Idaho City, and Boulder Creek, respectively. Consequently, many families were not represented in all replicates at any planting site. And more importantly, several families were not represented at all planting sites. The resultant imbalance precluded calculation of unbiased least squares estimates and weightings for variance components involving interactions of families and planting sites.

Table 1.--Form of the analyses of variance and expected mean squares

\begin{tabular}{lc}
\hline Source of variance & Expected mean squares ${ }^{2}$ \\
Replications & $\sigma^{2} E_{1}+\sigma^{2} E_{2}+k_{4} \sigma_{T / P}^{2}+k_{6} \sigma_{P}^{2}+k_{7} \sigma_{R}^{2}$ \\
Populations & $\sigma^{2} E_{1}+\sigma^{2} E_{2}+k_{3} \sigma_{T / P}^{2}+k_{5} \sigma_{P}^{2}$ \\
Trees/Populations & $\sigma^{2} E_{1}+\sigma^{2} E_{2}+k_{2} \sigma_{T / P}^{2}$ \\
Experimental Error & $\sigma^{2} E_{1}+\sigma^{2} E_{2}$ \\
Within & $\sigma^{2} E_{1}=\sigma^{2}{ }_{W} / k_{1}$
\end{tabular}

${ }^{1}$ Contains all sources of variation involving interactions of replication

2 where:

$\begin{array}{rrrrr}\mathrm{k}_{1}= & \frac{\text { Holcomb }}{1.79} & \frac{\text { Idaho City }}{1.88} & \frac{\text { Boulder Creek }}{\text { Jack's Creek }} \\ \mathrm{k}_{2}= & 6.06 & 8.09 & 2.79 & 1.51 \\ \mathrm{k}_{3}= & 6.71 & 8.54 & 7.93 & 3.71 \\ \mathrm{k}_{4}= & .36 & .19 & 8.53 & .44 \\ \mathrm{k}_{5}= & 41.79 & 57.47 & .20 & .66 \\ \mathrm{k}_{6}= & .06 & .01 & 54.91 & .13 \\ \mathrm{k}_{7}= & 161.30 & 213.47 & 215.15 & 94.84\end{array}$


Although mortality was generally high, little can be attributed to environmental maladaptation. Most death occurred within 2 years after planting. Whereas pocket gophers accounted for the high mortality at Jack's Creek and Holcomb, root rots were prevalent at Idaho City. Since more than 8,000 trees were planted at each site, even high levels of mortality could be absorbed without complete invalidation of statistical analyses. Thus, high mortality should have negligible effects on the interpretation of results.

Results of the analyses of variance (table 2) indicate statistical significance for all sources of variance at each planting site. Main interest for tree improvement, however, involves the genetic variances associated with the effects of populations and effects of maternal trees within populations. Whereas the former effects reflect population differentiation on which seed zoning relies, the latter represent the inheritable differences among families on which intensive tree improvement programs are based. Depending on tree age and planting site, effects of populations account for 8 to 35 percent of the genetic variance (table 3). Thus, most of the genetic variance exists within populations.

Table 2.--Results of analyses of variance for each location. Variance components $\left(\sigma^{2}\right)$ are derived according to Table 1

\begin{tabular}{|c|c|c|c|c|c|c|}
\hline \multirow[b]{2}{*}{ Source of variance } & \multicolumn{6}{|c|}{ Height at age } \\
\hline & d. f. & $\begin{array}{l}\text { Eight } \\
\text { Mean } \\
\text { Square }\end{array}$ & $\sigma^{2}$ & d.f. & $\begin{array}{l}\text { Eleven } \\
\text { Mean } \\
\text { Square }\end{array}$ & $\sigma^{2}$ \\
\hline \multicolumn{7}{|l|}{ Holcomb } \\
\hline Replication & 9 & $7366 * *$ & 43 & 9 & $24982 * *$ & 148 \\
\hline Populations & 36 & $920 * *$ & 7 & 36 & $2217 * *$ & 14 \\
\hline Trees/pops. & 227 & $601 * *$ & 44 & 227 & 1571 ** & 83 \\
\hline Expt. Error & 1355 & $335 * *$ & 125 & 1363 & $1069 * *$ & 448 \\
\hline Within & 2244 & 210 & $1_{376}$ & 2236 & 620 & ${ }^{1} 1110$ \\
\hline \multicolumn{7}{|l|}{ Idaho City } \\
\hline Replication & 9 & $8291 * *$ & 37 & 9 & $23851 * *$ & 107 \\
\hline Populations & 36 & $1541 * *$ & 15 & 36 & $3413 * *$ & 30 \\
\hline Trees/pops. & 225 & $660^{* \star}$ & 33 & 225 & $1666^{* *}$ & 84 \\
\hline Expt. Error & 1875 & $396 * *$ & 124 & 1864 & $987 * *$ & 403 \\
\hline Within & 3006 & 272 & ${ }^{1} 511$ & 3024 & 584 & ${ }^{1} 1098$ \\
\hline \multicolumn{7}{|l|}{ Boulder Creek } \\
\hline Replication & 9 & $6316 * *$ & 27 & 9 & $18735 * *$ & 82 \\
\hline Populations & 36 & 1571 ** & 15 & 36 & $3489 * *$ & 33 \\
\hline Trees/pops. & 231 & $698^{* *}$ & 38 & 231 & 1631 ** & 65 \\
\hline Expt. Error & 1869 & $394 * *$ & 225 & 1879 & $1112^{\star *}$ & 663 \\
\hline Within & 4934 & 169 & $1_{471}$ & 4924 & 448 & 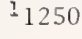 \\
\hline Jack's Creek & & & & & & \\
\hline Replication & 9 & $6333 * *$ & 61 & 9 & $42508 * *$ & 426 \\
\hline Populations & 36 & 1238 ** & 19 & 36 & 3381 ** & 19 \\
\hline Trees/pops. & 221 & $699 * *$ & 61 & 221 & $2726^{* *}$ & 217 \\
\hline Expt. Error & 639 & 474 ** & 109 & 717 & $1921 * *$ & 682 \\
\hline Within & 944 & 364 & ${ }^{1} 550$ & 949 & 1239 & ${ }^{1} 1870$ \\
\hline
\end{tabular}

**Statistically significant at the 1 percent level of probability.

$1_{\sigma^{2}} w$ as defined in table 1 . 
Table 3.--Ratios of genetic components of variance. Symbols are defined in table 1

\begin{tabular}{|c|c|c|c|}
\hline \multirow[b]{2}{*}{ Location } & & $\begin{array}{l}\text { ion genetic } \\
\text { table to popu } \\
\frac{\sigma^{2} \mathrm{P}}{\sigma_{\mathrm{p}}^{2}+\sigma^{2} \mathrm{~T} / \mathrm{P}}\end{array}$ & \\
\hline & $\begin{array}{l}\text { Age } \\
\text { eight }\end{array}$ & & $\begin{array}{c}\text { Age } \\
\text { eleven }\end{array}$ \\
\hline Ho 1 comb & 0.14 & & 0.15 \\
\hline Idaho City & .32 & & .26 \\
\hline Boulder Creek & .29 & & .34 \\
\hline Jack's Creek & .24 & & .08 \\
\hline
\end{tabular}

Variance components were also used to estimate family heritabilities, ratios of the additive genetic variance to the total phenotypic variance (table 4). Heritabilities were used to estimate expected response to half-sib family selection (Falconer 1960) and the percent gain expected next generation if present plantations are rogued at two intensities. Values of $\mathrm{h}^{2}$ presented in table 4 , however, are subject to conflicting sources of error. On one hand, progenies of wind-pollinated wild trees are expected to be slightly more closely related than actual half-sibs (Namkoong 1966); thus, present methods of calculation overestimate actual heritabilities. But conversely, part of the variance among populations in these tests reflects differential ecological adaptations. To the extent that maladaptations have reduced the potential variance among populations, estimates of additive genetic variances and heritabilities are deflated.

Finally, estimates of the additive genetic variance from single planting sites are confounded by interactions of genotype and environment (Namkoong and others 1966). But, genetic gains for ponderosa pine in Idaho will accrue within seed zones which still have not been delineated. Appropriate calculations of heritabilities should include inflation of additive genetic variances by genotype-environment interactions (Namkoong 1979). Consequently, the heritabilities presented in table 4 are appropriate if one assumes that each test site represents an individual seed zone.

Thus, even though estimates of heritabilities are subject to conflicting sources of bias, values are likely approximate. Consequently, if 70 percent of the shortest families are rogued at each planting, a subsequent population produced from the remaining 30 percent should realize a gain over the unselected population of at least 7 percent in 1l-year height (table 4). Again because of excessive mortality, values from the Jack's Creek planting are subject to greatest bias. 


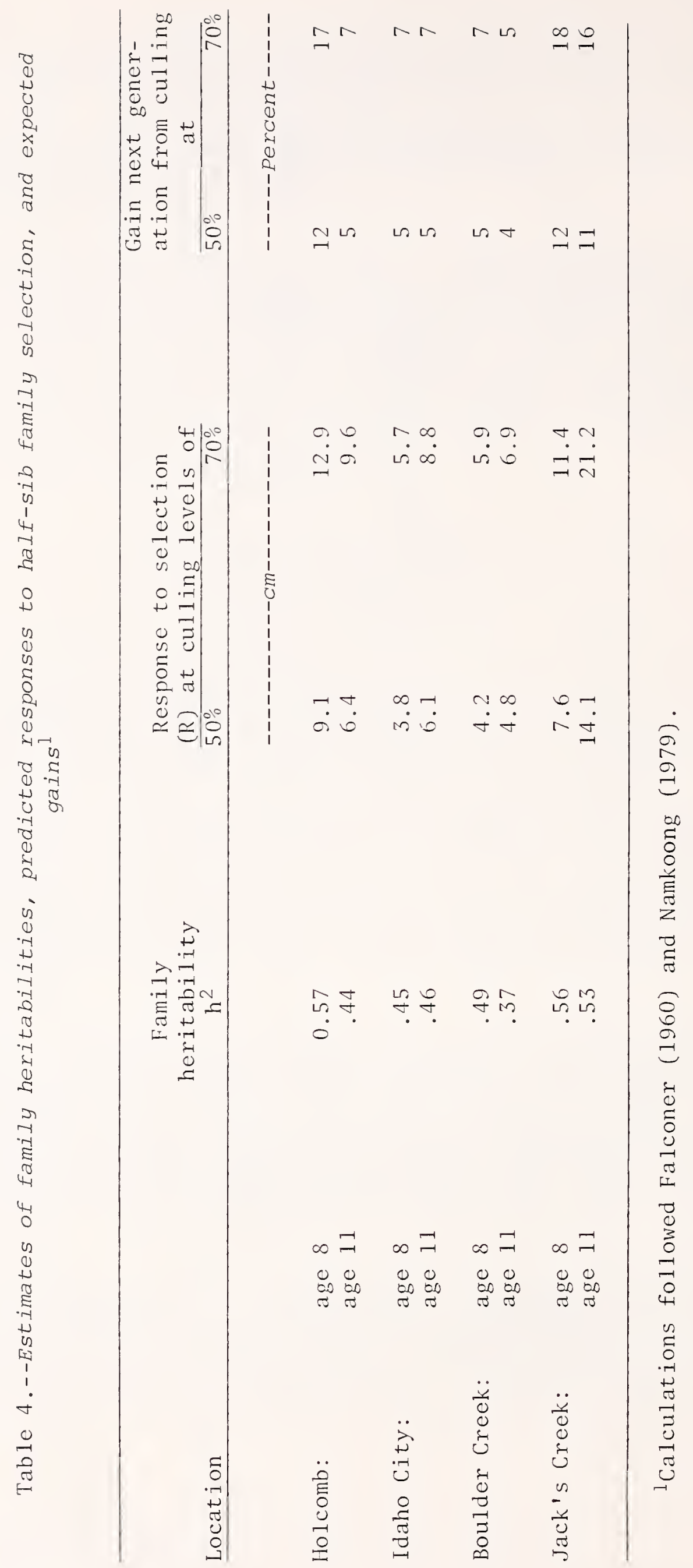


Heavy snow accumulations at Boulder Creek resulted in damage to stems of 69 percent of the trees. In order to determine if families or populations differed in ability to withstand snow accumulations, chi-square analyses were made on the number of individuals within families that exhibited straight stems and on the number of individuals that suffered snow damage. Since families had been established in 4-tree row plots, analyses were made without regard to replication. Family means for the percentage of trees with straight stems varied from 0 to 100; but population means ranged from 6 to 41 percent. Analyses of chi-square showed that families differed significant $1 \mathrm{y}$ at the 1 percent 1 evel of probability $\left(x^{2}=341.9\right.$ with $\left.268 \mathrm{~d} . \mathrm{f}.\right)$; however, no differences could be detected among populations ( $x^{2}=32.8$ with 36 d.f.). Since the correlation among family means for the percentage of trees damaged by snow with the percentage of trees with straight stems was -0.82 , chi-square analyses for snow damage also indicated significant differences among families but no differences among populations. And, contrary to results of a provenance study in northern Idaho (Rehfeldt and Cox 1975), there was no indication that trees with the slowest growth rates suffered the least damage: the correlation between mean family height at age 11 and proportion of trees damaged by snow was a nonsignificant value of -0.07 . Snow damage at Boulder Creek, however, was so high that subtle differences among families and populations remain undetected.

Population differentiation provides the basis for developing seed transfer rules for afforestation; however, to assess differentiation according to geographic and ecologic conditions of the seed source required mean values for each population at each planting site were required. But, all families and populations were not represented in all replicates in each planting, and replicates had significant effects on performance (table 2). Thus, mean values were confounded by the effects of replication. Effects of confounding were reduced by adjusting plot means for replication before lopulation means were calculated:

$$
\hat{Y}_{i j k}=\bar{X}_{i j k}-\bar{X}_{j k}+\bar{X}_{\cdot}{ }_{k} \quad ;
$$

where,

$$
\begin{aligned}
& \bar{X}_{i j k}=\text { plot mean for family } i \text { of replicate } j \text { of plantation } k, \\
& \bar{X}_{j k}=\text { mean value for replicate } j \text { of plantation } k, \\
& \bar{X}_{{ }_{k}}=\text { mean value for planting } k, \\
& \hat{Y}_{i j k}=\text { adjusted plot means. }
\end{aligned}
$$

Then, differentiation of populations in relation to geographic and ecologic conditions of the seed source was assessed by multiple regression models:

$$
\hat{Y}_{i j}=b_{0}+b_{1} x_{1 i}+b_{2} x_{2 i}+b_{3} x_{3 i} ;
$$

where,

$$
\begin{aligned}
\hat{Y}_{i j}= & \text { mean value adjusted for effects of replication for population } i \text { at } \\
& \text { planting } j, \\
x_{1 i}= & \text { elevation at the origin of population } i, \\
x_{2 i}= & \text { latitude at the origin of population } i \\
x_{3 i}= & \text { longitude at the origin of population } i .
\end{aligned}
$$


Results of regression analyses are presented in table 5 for height at ages 8 and 11. Similar analyses were made on the percentage of trees with straight stems and the percentage of trees damaged by snow for each population represented at Boulder Creek. That neither of the last two models was statistically significant is depicted by a lack of significance of simple correlation coefficients involving these two independent variables and the dependent variables (table 6). Since population differentiation was not reflected in the percentages of straight-stemmed and snowdamaged trees, results of multiple regression analyses are not presented.

Table 5 shows that regression models for both ages at all planting sites were statistically significant and accounted for 24 to 41 percent of the variance among populations. Whereas elevation of the seed source had strong negative influences on mean height of populations, latitude and longitude had positive influences; these relationships were also apparent in simple correlation coefficients (table 6). Standardized partial regression coefficients, which reflect the relative importance of the independent variables in determining the dependent variable, suggest that population differentiation is controlled primarily by elevation (table 5). Strong relationships between elevation and population differentiation have also been observed for ponderosa pine in California (Callaham and Liddicoet 1961) and in northern Idaho and western Montana (Madsen and Blake 1977).

Yet, multiple regression models accounted for less than half of the variance among populations. Indeed, 60 to 75 percent of the variance was unexplained. Two of the many possible sources of extraneous variance include an incomplete model and interrelationships among variables that deviated from the linear. In regard to the latter possibility, a visual examination of relationships between residuals from regression and the independent variables did not support transformation of independent variables. And, even though it would be nearly impossible to develop a model that includes all relevant independent variables, additional analyses were made to incorporate habitat types (recurring climax plant communities) into the model presented above. The 37 populations represented 7 individual habitat types and 3 major series of habitat types. The regression model presented previously was adjusted by including a constant term for each habitat type represented; separate models were fitted for individual habitat types or series' of habitat types. However, models in which habitat types were included as constant terms reduced significant models (table 5) to insignificance, primarily because habitat types absorbed six degrees of freedom but accounted for no variance in addition to that already explained by previous models.

That habitat types did not account for variance additional to that associated with latitude, longitude and elevation is illustrated by simple relationships among variables (table 6). Neither the series of habitat types nor individual habitat types were significantly associated with the mean height of populations at any planting site. Yet, even though relationships are insignificant, individual habitat types accounted for relatively large proportions of variance in mean height of populations. However, these relationships seem to be mediated indirectly through strong relationships of habitat types with elevation and latitude, two variables closely associated with the dependent variables. Apparently habitat types do not contribute directly to differentiation of populations, a conclusion quite similar to those for Douglas-fir in both western Oregon (Campbell and Franklin in press) and northern Idaho (Rehfeldt 1979). 
Table 5.--Results of multiple regression analyses presented in terms of regression coefficients (b) and standardized partial regression coefficients ( $\left.b^{\prime}\right)$

Variable $\frac{\text { Holcomb }}{b} \frac{\text { Tdaho City }}{b} \quad \frac{\text { Boulder Creek }}{b^{\prime}} \quad \frac{\text { Jack's Creek }}{b^{\prime}} \frac{b^{\prime}}{b^{\prime}}$

A. Height at age eight

\begin{tabular}{cccccccrr}
$x_{1}$ Elevation & -0.220 & -0.38 & -0.230 & -0.33 & -0.352 & -0.47 & -0.388 & -0.45 \\
$x_{2}$ Latitude & 2.679 & .31 & 2.589 & .24 & .674 & .06 & 3.867 & .30 \\
$x_{3}$ Longitude & 1.356 & .12 & 2.424 & .17 & 1.087 & .07 & -.602 & -.03 \\
\hline$b_{0}$ & 68.07 & 62.43 & 90.92 & 72.11 \\
$R^{2}$ & $.39^{* *}$ & $.33^{* *}$ & $.28^{*}$ & $.34^{* *}$ \\
$s^{2}{ }_{y . x}$ & 15.28 & 24.65 & 30.45 & 36.78
\end{tabular}

B. Height at age eleven

\begin{tabular}{ccccccccc}
$x_{1}$ Elevation & -.466 & -.50 & -.313 & -.29 & -.347 & -.33 & -.458 & -.31 \\
$x_{2}$ Latitude & 3.366 & .24 & 3.360 & .20 & 1.274 & .08 & 4.235 & .20 \\
$x_{3}$ Longitude & 1.163 & .06 & 5.337 & .25 & 5.703 & .18 & 5.287 & .19 \\
\hline$b_{0}$ & 138.83 & 100.44 & 124.50 & 95.58 \\
$R^{2}$ & $.41^{* *}$ & $.35^{* *}$ & $.24^{*}$ & $.29^{*}$ \\
$\mathrm{~s}^{2} y_{* x}$ & 38.33 & 59.93 & 60.79 & 108.81
\end{tabular}

Table 6.--Simple linear relationships among independent variabiles and between independent and dependent variables. Double and single asterisks code statistical significance at the 5 percent and 1 percent levels of probability, respectively

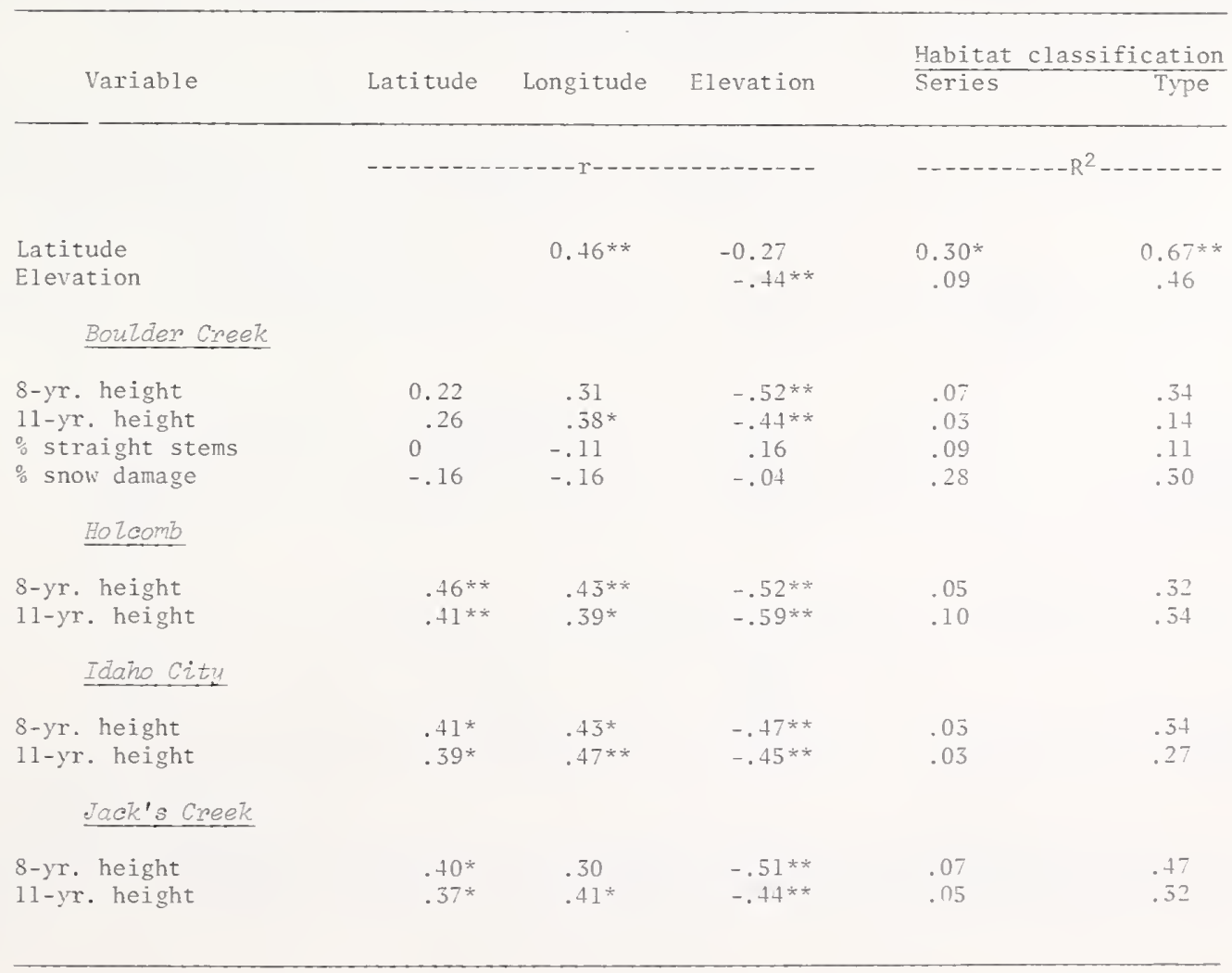




\section{DISCUSSION}

Results have illustrated considerable genetic diversity among and within ponderosa pine populations of southwest Idaho. Consequently, programs of tree improvement can offer genetic gains from seed zoning, population selection within zones, and family selection within populations. Yet, realization of gains in productivity requires that improved genotypes are adapted to environments in which they will be planted. Thus, actual gains will occur within seed zones or breeding units, geographic and ecologic stratifications of forest regions into units within which trees are similarly adapted.

Development of seed zones from the present results follows procedures used for Douglas-fir in north Idaho (Rehfeldt 1979). Accordingly, analyses of variance allow calculation of mean differences among populations that are associated with least significant differences ( $1 s d$ ) at various levels of probability (Steel and Torrie 1960). Then, multiple regression models were used to calculate the distances in latitude, longitude and elevation required to alter dependent variables an amount equal to the least significant differences derived above. Geographic distances associated with mean differences among populations that are significant at ${ }^{1 s d_{0.8}}$ are given in table 7 . As argued previously, a relatively low level of probability $(0.8)$ seems intuitively conservative for avoiding the error of accepting no differences among populations when differences actually exist.

If the minimum geographic distances of table 7 are accepted for limiting seed transfer, ponderosa pine seeds in southwest Idaho should not be transferred more than $450 \mathrm{~m}$ elevation, 1.7 degrees longitude or 2.2 degrees latitude. This suggests that for the area under study (fig. 1) seed can be transferred without regard to longitude or latitude; zones can be based exclusively on elevation.

Table 7.--Geographic distances associated with mean differences among seed sources that correspond to a significance level of 80 percent

Holcomb Idaho City Boulder Creek Jack's Creek

A. Height at age eight

Elevation (m)

Latitude (degrees)

Longitude (degrees)

B. Height at age eleven

Elevation (m)

Latitude (degrees)

Longitude (degrees)
900

2.4

4.9

687

3.1

9.1
778

2.2

2.4

910

2.7

1.7
459

7.8

4.9

790

2.6

16.7 
Even though the limits of seed transfer suggested by the present results are more restrictive than those recommended for western white pine (Steinhoff 1979) and are more liberal than those suggested for Douglas-fir in north Idaho (Rehfeldt 1979), they should be regarded as preliminary. Present techniques relied on statistical detection of differences among populations. Since error variances were relatively high, statistical power tended to be low. Moreover, seed zones must involve numerous adaptational features. In addition to analyses of tree height, corroborative data are necessary on variables such as phenology and cold hardiness before limits of seed transfer are finalized. Nevertheless, there is little doubt that losses in productivity from maladaptation can be reduced by seed zoning in reforestation.

Realization of potential genetic gains begin with the yield of genetically improved seeds from seed orchards. Original objectives of the current improvement program included possibilities of converting half-sib progeny tests to seed orchards. Indeed, a gain of at least 7 percent can be expected in 11-year height of progenies from the current plantings after 70 percent of the shortest families are removed. But, if it is assumed that each planting site represents a seed zone of the size suggested above, only one-third to one-half of the 37 populations would actually represent the zone associated with each planting site. Consequently, if the present plantings are rogued first according to seed zones and secondly according to performance, the genetic base may be depleted such that the desirability of seed orchards is questionable.

Current test plantations will yield data from 16-year-old trees before thinning is necessary. The next data set will best address future objectives of current progeny tests. But more importantly, future data will allow comparison with results obtained with ponderosa pine in California: mean differences among families changed greatly between ages 20 and 25 (Namkoong and Conkle 1976). If applicable to the same species in Idaho, the California results imply that family evaluations should be delayed as long as possible.

\section{PUBLICATIONS CITED}

Callaham, R. Z., and A. R. Liddicoet.

1961. Altitudinal variation at 20 years in ponderosa and Jeffrey pines. J. For. $59: 814-820$.

Campbel1, R. K., and J. F. Franklin.

(In press) Seed zone classification by habitat type and elevation - a comparison in western Oregon. For. Sci.

Falconer, D. S.

1960. Introduction to quantitative genetics. 365 p. Ronald Press, New York.

Madsen, J. L., and G. M. Blake.

1977. Ecological genetics of ponderosa pine in the northern Rocky Mountains.

Silvae Genet. 26:1-7.

Namkoong, G.

1966. Inbreeding effects on estimation of genetic additive variance. For. Sci. $12: 8-13$.

Namkoong, G.

1979. Introduction to quantitative genetics in forestry. USDA For. Serv. Tech.

Bul1. 1588. Washington, D.C.

Namkoong, G., and M. T. Conkle.

1976. Time trends in genetic control of height growth in ponderosa pine. For. Sci. 22:2-12. 
Namkoong, G., E. B. Snyder, and R. W. Stonecypher.

1966. Heritability and gain concepts for evaluating breeding systems such as seedling orchards. Silvae Genet. 15:76-84.

Rehfeldt, G. E.

1978. Genetic differentiation of Douglas-fir populations from the northern Rocky Mountains. Ecology 59:1264-1270.

Rehfeldt, G. E.

1979. Ecological adaptations in Douglas-fir (Pseudotsuga menziesii var. glauca) populations. I. North Idaho and northeast Washington. Heredity 43:

Rehfeldt, G. E., and R. G. Cox.

1975. Genetic variation in a provenance test of 16-year-old ponderosa pine. USDA

For. Serv. Res. Note INT-201. p. Intermt. For. and Range Exp. Stn., Ogden, Utah.

Steel, R. G. D., and J. H. Torrie.

1960. Principles and procedures of statistics. 481 p. McGraw-Hill, New York.

Steinhoff, R. J.

1979. Variation in early growth of western white pine in northern Idaho. USDA

For. Serv. Res. Pap. INT-222. p. Intermt. For. and Range Exp. Stn., Ogden, Utah.

Wang, C. W.

1967. The genetic improvement of ponderosa pine in Idaho. Univ. Idaho, Moscow, For., Wildlife and Range Exp. Stn. Note 7, 7 p.

Wang, C. W.

1977. Genetics of ponderosa pine. USDA For. Serv. Res. Pap. W0-34. p. Washington, D.C.

Wang, C. W., and R. K. Patee.

1974. Variation in seed characteristics and seedling growth of open pollinated ponderosa pine progenies. Univ. Idaho, Moscow, For., Wildlife and Range Exp. Stn., Pap. 15, $11 \mathrm{p}$.

Wang, C. W. , and R. K. Patee.

1976. Regional variation of ponderosa pine, the 5-year result. Univ. Idaho., Moscow, For., Wildlife and Range Exp. Stn., Bull. 10, 7 p. 
Rehfeldt, Gerald E.

1979. Genetic Variation in Southern Idaho Ponderosa Pine Progeny Tests After 11 Years. USDA For. Serv. Gen. Tech. Rep. INT-75, 12 p. Intermt. For. and Range Exp. Stn., Ogden, Utah 84401 .

Comparisons of the 8- and 11-year heights among progenies from 268 half-sib families of ponderosa pine from 37 southwest Idaho populations were made on four test sites. Multiple regression analyses suggested that seed for afforestation should not be transferred more than $450 \mathrm{~m}$ eli tion, 1.7 degrees longitude, and 2.2 degrees latitude. Habitat types can be neglected in seed zoning. Quantitative genetic analyses provided estimates of family heritabilities in ll-year height that ranged from 0.37 to 0.53 for the various planting sites. Consequently, genetic gains of about 7 percent can be expected readily in the height of ll-year-old progenies from selected families.

KEYWORDS: Genetic variation, ponderosa pine, heritability, seed zoning.

Rehfeldt, Gerald E.

1979. Genetic Variation in Southern Idaho Ponderosa Pine Progeny Tests After 11 Years. USDA For. Serv. Gen. Tech. Rep. INT-75, 12 p. Intermt. For. and Range Exp. Stn., Ogden, Utah 84401 .

Comparisons of the 8- and 1l-year heights among progenies from 268 half-sib families of ponderosa pine from 37 southwest Idaho populations were made on four test sites. Multiple regression analyses suggested that seed for afforestation should not be transferred more than $450 \mathrm{~m}$ elevation, 1.7 degrees longitude, and 2.2 degrees latitude. Habitat types can be neglected in seed zoning. Quantitative genetic analyses provided estimates of family heritabilities in ll-year height that ranged from 0.37 to 0.53 for the various planting sites. Consequently, genetic gains of about 7 percent can be expected readily in the height of ll-year-old progenies from selected families.

KEYWORDS: Genetic variation, ponderosa pine, heritability, seed zoning. 
The Intermountain Station, headquartered in Ogden, Utah, is one of eight regional experiment stations charged with providing scientific knowledge to help resource managers meet human needs and protect forest and range ecosystems.

The Intermountain Station includes the States of Montana, Idaho, Utah, Nevada, and western Wyoming. About 273 million acres, or 85 percent, of the land area in the Station territory are classified as forest and rangeland. These lands include grasslands, deserts, shrublands, alpine areas, and well-stocked forests. They supply fiber for forest industries; minerals for energy and industrial development; and water for domestic and industrial consumption. They also provide recreation opportunities for millions of visitors each year.

Field programs and research work units of the Station are maintained in:

Boise, Idaho

Bozeman, Montana (in cooperation with Montana State University)

Logan, Utah (in cooperation with Utah State University)

Missoula, Montana (in cooperation with the University of Montana)

Moscow, Idaho (in cooperation with the University of Idaho)

Provo, Utah (in cooperation with Brigham Young University)

Reno, Nevada (in cooperation with the University of Nevada)

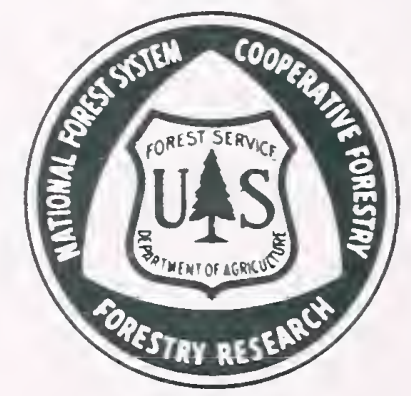

